\title{
The renin-angiotensin system and male reproduction: new functions for old hormones
}

\author{
P S Leung and C Sernia ${ }^{1}$ \\ Department of Physiology, Faculty of Medicine, The Chinese University of Hong Kong, Shatin, Hong Kong \\ ${ }^{1}$ Department of Physiology and Pharmacology, University of Queensland, Brisbane, Australia
}

(Requests for offprints should be addressed to P S Leung; Email: psleung@cuhk.edu.hk)

\begin{abstract}
The blood-borne renin-angiotensin system (RAS) is known best for its role in the maintenance of blood pressure and electrolyte and fluid homeostasis. However, numerous tissues show intrinsic angiotensin-generating systems that cater for specific local needs through actions that add to, or differ from, the circulating RAS. The male reproductive system has several sites of intrinsic RAS activity. Recent focus on the epididymis, by our laboratories and by others, has contributed important details about the local RAS in this tissue. The RAS components have been localized morphologically and topographically; they have been shown to be responsive to androgens and to hypoxia; and angiotensin has been shown to influence tubular, and consequently, fluid secretion. Components of the RAS have also been found in the testis, vas deferens, prostate and semen. Angiotensin II receptors, type 1 and, to a lesser extent, type 2 are widespread, and angiotensin IV receptors have been localized in the prostate. The roles of the RAS in local processes at these sites are still uncertain and have yet to be fully elucidated, although there is evidence for involvement in tubular contractility, spermatogenesis, sperm maturation, capacitation, acrosomal exocytosis and fertilization. Notwithstanding this evidence for the involvement of the RAS in various important aspects of male reproduction, there has so far been a lack of clinical evidence, demonstrable by changes in fertility, for a crucial role of the RAS in male reproduction. However, it is clear that there are several potential targets for manipulating the activity of the male reproductive system by interfering with the locally generated angiotensin systems.
\end{abstract}

Journal of Molecular Endocrinology (2003) 30, 263-270

\section{Introduction}

The renin-angiotensin system (RAS) is principally a blood-borne hormone system that regulates blood pressure directly by its vasopressor action and indirectly via a cluster of central and peripheral mechanisms that integrate pressor, electrolyte and fluid homeostasis (Reid et al. 1978, Stroth \& Unger 1999, De Gasparo et al. 2000). The effector hormone of the RAS is predominantly angiotensin II (AngII), with AngIII, AngIV and Ang $(1-7)$ relegated to lesser, albeit ascendant, roles. Nevertheless, the actions of the RAS reach beyond the cardiovascular system and include such diverse targets as the pancreas (recently reviewed (Leung \& Carlsson 2001)), and various components of the female and male reproductive systems (Vinson et al. 1997, Poisner 1998, Speth et al. 1999). The angiotensins in these tissues are frequently of a paracrine/autocrine origin, from the activity of local tissue RAS (Deschepper et al. 1986, Campbell 1987, Phillips et al. 1993). The focus of this review is on the emerging roles for local RAS in male reproduction, with some emphasis on the contributions to our particular area of research on the expression, regulation and functions of the RAS in the epididymis. 
Table 1 Summary of the components of the RAS found in the male reproductive system. References are not exhaustive but representative. Asterisk indicates references at the gene level of RAS components; otherwise references are to the protein level of RAS components

\section{RAS component Location}

Angiotensinogen Testis (Leydig cells); epididymis; prostate

Renin

ACE

Angiotensin II

Angiotensins III, IV or (1-7)

Angiotensin receptors: $\mathrm{AT}_{1 \mathrm{a}}$, $\mathrm{AT}_{1 \mathrm{~b}}$

Angiotensin receptor: $\mathrm{AT}_{2}$

Angiotensin binding sites: $\mathrm{AT}_{4}$, AT (1-7)
Leydig cells; epididymis; prostate

Leydig cells; seminiferous tubules; epididymis; prostate; spermatozoa; seminal plasma

Testis; epididymis; prostate; seminal plasma

Not reported

Testis (Leydig cells); epididymis; vas deferens; prostate; spermatozoa

Testis; epididymis; prostate

Prostate $\left(\mathrm{AT}_{4}\right)$

\section{Reference}

Dzau et al. 1987*, Wong \& Uchendu 1991, Leung et al. 1999*, Pinterova et al. 2000*, C Sernia, unpublished observations, M E Fabiani, unpublished observations*

Pandey et al. 1984a*, Deschepper et al. 1986*, Wong \& Uchendu 1991, Pinterova et al. 2000*, M E Fabiani, unpublished observations

El-Dorry et al. 1983, Pandey et al. 1984b, Berg et al. 1986, Wong \& Uchendu 1991, Mukhopadyay et al. 1995, Williams et al. 1995*, Kohn et al. 1998a, Pinterova et al. 2000*, Nassis et al. 2001*

Okuyama et al. 1988, Zhao et al. 1996, O'Mahony et al. 2000, Dinh et al. 2001b

Magnan \& Regoli 1979, Millan \& Aguilera 1988, Grove \& Speth 1989, Kitami et al. 1992*, Sum \& Cheung 1995, Vinson et al. 1995, Leung et al. 1997b, 1998*, Dinh et al. 2001a

Leung et al. 1997b, 1998a*, Speth et al. 1999, Dinh et al. 2001a

Dinh et al. 2001b

\section{Components of the RAS in the male reproductive system}

There is considerable evidence for the local synthesis of components of the RAS in male reproductive tissues, in seminal fluid and in spermatozoa (see reviews by Mukhopadyay et al. 1995, Vinson et al. 1997, Speth et al. 1999). AngII concentrations in the seminal plasma are three to five times higher than in blood plasma (O'Mahony et al. 2000). The capacity of sites in the testis, epididymis and prostate to synthesize AngII (see Table 1) and the presence of a blood-testis barrier restricting the entry of blood-borne substances, make it probable that the AngII in seminal plasma originates in the male reproductive tract. The details of male reproductive organs' ability to synthesize RAS components, at the levels of genes and/or proteins, are summarized in Table 1 . Furthermore, the localization of AngII to epithelial cells in the epididymis and prostate (Zhao et al. 1996, Dinh et al. 2001a) suggests that this peptide is generated by both intra- and extra-cellular mechanisms. Since most AngII antisera cross-react with several angiotensins, it is also possible that other angiotensins are synthesized in addition to AngII. In this regard, the presence of angiotensin receptor subtype $\mathrm{AT}_{4}$ in the human prostate is certainly a strong indication that the peptide AngIV is present (Dinh et al. 2001b).

The best evidence for a complete classic RAS exists for the testes, where angiotensinogen, renin, an angiotensin-converting enzyme (ACE) specific to the testis (ACET) (Esther et al. 1997, Hagaman et al. 1998), angiotensin receptor subtypes $\mathrm{AT}_{1}$ and $\mathrm{AT}_{2}$ and AngII have all been found. Interestingly, both renin and angiotensinogen mRNA are present and localized to the testicular Leydig cells of mouse testes (Pandey et al. 1984a, Deschepper et al. 1986, Dzau et al. 1987). These data suggest that a locally 
generated RAS is operating in the testes, which may be linked to a renin-dependent biosynthetic pathway. Moreover, ACET is found exclusively in late pachytene spermatocytes and mature spermatozoa (Berg et al. 1986, Sibony et al. 1993) while the somatic form of ACE (sACE) is found in the Leydig cells, epididymis and prostate (Nassis et al. 2001). The importance of ACET in fertility is discussed below.

The existence of an intrinsic RAS in the epididymis has been implicated by the presence of immunoreactive AngI, AngII, renin-like activity and ACE in cultures of rat epididymis (Wong \& Uchendu 1991). AngII (Zhao et al. 1996), $\mathrm{AT}_{1}$ and $\mathrm{AT}_{2}$ receptors (Grove \& Speth 1989, Leung et al. 1997a) have been localized to the epididymal epithelium. Angiotensinogen, the mandatory component for locally produced angiotensins, has been identified by Northern blot, PCR and Western blot (Leung et al. 1999, 2000). It has been localized to the epithelium by immunohistochemistry and in situ hybridization histochemistry (Leung et al. 1999). Western blot analysis of angiotensinogen identified a single $60 \mathrm{kDa}$ protein band similar to that observed for other tissues. Interestingly, renin mRNA has not been found in the epididymis (Leung et al. 1999, 2000), despite the presence of renin-like activity in epididymal cell cultures (Wong \& Uchendu 1991). This observation implies the presence of a non-classic RAS, at least in the epididymal epithelium, that uses alternate enzymes to renin. In fact, kallikrein, a renin-like enzyme, can result in direct generation of AngII, rather than the definitive enzymatic cascade of renin and ACE arising from the classic RAS (Maruta \& Arakawa 1983). In this regard, renin mRNA is also absent from rat testes (Campbell \& Habener 1986, Dzau et al. 1987) and the carotid body (Lam \& Leung 2002), indicating that renin-independence could be present in those tissues. However, it should be stressed that local angiotensins could also be generated by the action of plasma-derived renin from the kidney. While co-localization studies have not been attempted, the proximity of angiotensinogen, AngII and AT receptors suggests a paracrine/ autocrine action of locally generated AngII on the secretion of anion and fluid by the epididymal epithelium function (Leung et al. 1997a). This has been found to be the case in electrophysiological studies showing the action of AngII on anion secretion to be mediated by the $\mathrm{AT}_{1}$ receptor
(Leung et al. 1997b). In addition to the epididymal epithelium, AngII receptors have also been characterized and identified in epididymal fat tissue of rat and human origin (Crandall et al. 1993, 1994). Recently, mRNAs for angiotensinogen, renin, ACE and AngII receptors were identified and detected in the stromal vasculature of the fat tissue (Pinterova et al. 2000), indicating that a complete classic RAS may be operated in rat/human adipose tissue of the epididymis. The above data support the existence of either a classic or non-classic RAS in the epididymis that may modulate, via paracrine or autocrine action, epididymal functions such as anion excretion and, consequently, sperm activity.

There is now a body of evidence for a complete classic RAS in the prostate (Dinh et al. 2001a,b, 2002, Nassis et al. 2001). Indeed, the human prostate expresses angiotensinogen, renin, ACE, AngII, $\mathrm{AT}_{1}$ receptors and low amounts of $\mathrm{AT}_{2}$ receptors. While mRNA of angiotensinogen and renin are detected in the human prostate (Fabiani, unpublished observations), $\mathrm{AT}_{1}$ receptors were localized predominantly to periurethral stromal smooth muscle (Dinh et al. 2001a). The regulatory enzymes ACE and renin are localized to the epithelium. AngII immunoreactivity has been localized to the basal layer of the epithelium (Dinh et al. 2002). In addition, binding sites for $\mathrm{AT}_{4}$ receptors have been found in the prostate, localized to the glandular epithelium, as evidenced by an autoradiographic study (Dinh et al. 2001b). It is not known if these binding sites are identical to insulin-regulated aminopeptidase, as recently reported for brain $\mathrm{AT}_{4}$ receptors (Albiston et al. 2001).

\section{Regulation and functions of local RAS}

The functions discussed in this section are summarized in Fig. 1. There are considerable data for the regulation of RAS components in male reproductive tissues. Testicular renin, ACE, angiotensinogen and total AT receptors increase concomitantly with plasma gonadotropins at the onset, or immediately before, puberty (Hohlbrugger et al. 1982, Parmentier et al. 1983, Speth et al. 1999). Interestingly, AngII has been shown to inhibit Leydig cell function and is thus implicated in the local regulation of the testis by 


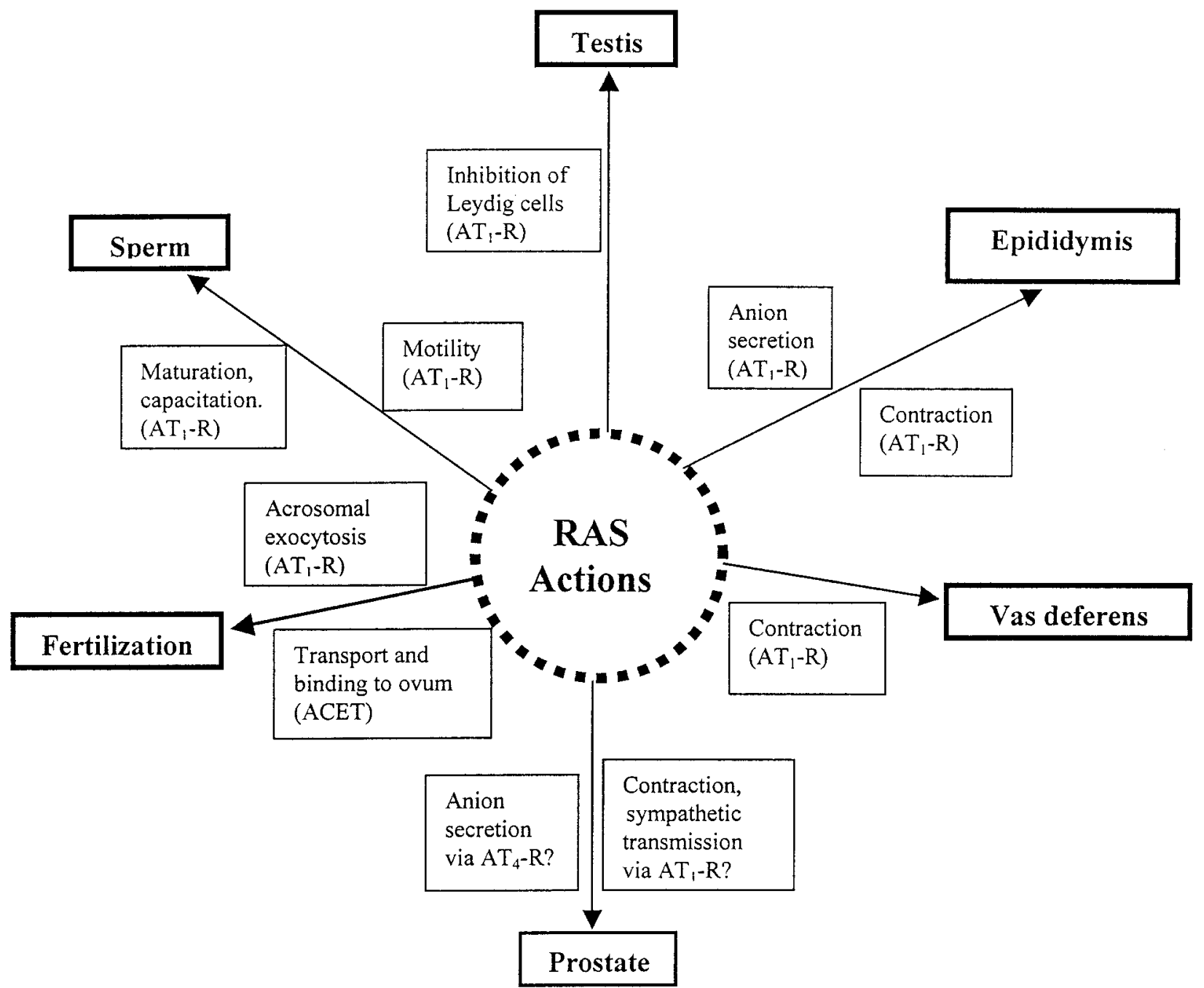

Figure 1 A summary of the functions of the local RAS in the male reproductive system. ?, indicates uncertainty. $A T_{1}-R$, angiotensin receptor subtype $1 ; \mathrm{AT}_{4}-\mathrm{R}$, angiotensin receptor subtype 4.

pituitary luteinizing hormone (Khanum \& Dufau 1988). In that study, AngII was found to inhibit adenylate cyclase activity in Leydig cell membranes and reduce basal and human chorionic gonadotropin-stimulated cAMP as well as testosterone production. These data suggest that locally produced AngII could negatively modulate luteinizing hormone stimulation of Leydig cells.

The association of RAS and hormone, such as testicular hormonal regulation of RAS, has been further demonstrated in other sites in male reproductive organs. In the epididymis, renin-like activity has been shown to be androgen-dependent (Uchendu 1995); more recent reports show that the expression of RAS, particularly at the levels of its precursor angiotensinogen and its $\mathrm{AT}_{1}$ receptor, is predominantly testosterone-dependent (Leung et al. 2000). The expression of epididymal $\mathrm{AT}_{1}$ and $\mathrm{AT}_{2}$ receptors differs in mature and immature rats, with $\mathrm{AT}_{2}$ receptor being expressed predominantly in immature rats (Leung et al. 1998a). These differences may imply that the $\mathrm{AT}_{2}$ receptor mediates growth and differentiation in the immature male reproductive system and appears not to be involved in the secretory activity in the mature epididymis.

Grove \& Speth (1989), in a dramatic display of expulsive power by the isolated epididymis, showed the contractile action of AngII. The $\mathrm{AT}_{1}$ receptor has been shown to mediate directly the anion 
secretion by the epididymis, a process which is predominantly dependent on testicular testosterone (Leung et al. 2002). The action of AngII on anion secretion is mediated by the stimulation of the prostaglandin $\mathrm{PGE}_{2}$ (Leung et al. 1998b). The expression of cyclooxygenase, a principal enzyme in prostaglandin synthesis, is controlled by testicular androgens (Wong et al. 1999, Cheuk et al. 2000). These data suggest that androgens control anion secretion in the epididymis by stimulating components of the RAS and of prostaglandin synthesis. Disruptions of the RAS or prostaglandin pathways are therefore potential sites for the management of epididymal functions, thus affecting sperm maturation and expulsion.

In addition to hormonal regulation, local RAS is also responsive to various stresses and pathological conditions (Leung \& Carlsson 2001). In the epididymis, chronically hypoxic stress attenuates the transcriptional and post-transcriptional expression of angiotensinogen, and by implication, the local production of angiotensins. Since AngII is involved in epithelial anion secretion (Leung et al. 1997b), this down-regulation would be expected to decrease anion and thus fluid secretion by the epididymis, which would in turn lead to the disturbances in testicular function observed in chronic hypoxia (Leung et al. 2001).

The prostate has been the latest site of investigation for a local RAS. In a series of publications from the same laboratory (Dinh et al. 2001a,b, 2002, Fabiani et al. 2001, Nassis et al. 2001), all components of the RAS in the human prostate, including angiotensinogen, renin, $\mathrm{ACE}, \mathrm{AT}_{1}$ receptors as well as AngII itself, were identified and localized to the glandular epithelium (ACE, AngII, $\mathrm{AT}_{4}$ receptor) and periurethral stromal smooth muscle $\left(\mathrm{AT}_{1}\right.$ receptor). The localization of these components, and the stimulation of noradrenaline release from prostatic nerve endings by AngII, suggest roles in anion secretion, tubular contractility and the enhancement of sympathetic nerve activity (See Fig. 1). Furthermore, the RAS was found to be overactive in benign prostatic hyperplasia $(\mathrm{BPH})$. Interestingly, renin and ACE protein at both the gene and protein levels, as well as AngII, are increased, while $\mathrm{AT}_{1}$ receptors are down-regulated in $\mathrm{BPH}$. These findings show an association of local RAS activity with a common clinical condition, suggesting a potential therapeutic approach by the inhibition of the local RAS. On the other hand, the presence of $\mathrm{AT}_{4}$ receptors also opens up the way to further studies in this new pathway for angiotensin action.

\section{RAS and male fertility}

The importance of local RAS for male fertility is presently unclear, and to some extent, debatable. Gur et al. (1998) showed $\mathrm{AT}_{1}$ receptors in the tail of non-capacitated sperm, and head-to-tail distribution in capacitated sperm. AngII induced acrosomal exocytosis only in capacitated sperm. AngII has been shown to maintain sperm motility via an $\mathrm{AT}_{1}$ receptor-mediated mechanism (Vinson et al. 1995, 1996). However, some studies with ACE inhibitors or AngII receptor antagonists have reported no effect on fertility in rats (Dostal et al. 1991, Spence et al. 1995). Although the ACE inhibition does not exhibit a direct effect on the capacitation process or acrosome reaction, decreased binding of human spermatozoa to oocytes after inhibition by captopril may indicate that kininase II is involved in sperm-egg interactions (Kohn et al. 1998b). In addition, knockout mice lacking ACE show infertility of the males only (Krege et al. 1995). Restoring ACET corrected the infertility, while sperm expression of the sACE did not, demonstrating the selective dependence of male fertility on ACET (Ramaraj et al. 1998, Kessler et al. 2000). The defect appears to be poor sperm migration in the oviduct and a failure of ovum penetration. The failure of sACE replacement to correct the infertility and the normal fertility of angiotensinogen knockout mice (Kim et al. 1995) indicate that the absence of angiotensins is not the crucial block and that some other ACET-specific substrate is involved (Kessler et al. 2000). However, this view is challenged by a more recent study in angiotensinogen-deficient mice by Tempfer et al. (2000), which showed a decreased fertility attributable in part to male infertility. Interestingly, decreased ex utero survival rate is observed in mutant mice when both $\mathrm{AT}_{1}$ receptor subtypes $\left(\mathrm{AT}_{1 \mathrm{a}}\right.$ and $\left.\mathrm{AT}_{1 \mathrm{~b}}\right)$ are knocked out, which is quantitatively similar to that of the angiotensinogen knockout (Tsuchida et al. 1998, Doan et al. 2001). These data suggest that major biological functions of endogenous AngII elucidated by the abnormal phenotype of angiotensinogen knockout mice are mediated by the $\mathrm{AT}_{1}$ receptors. 
The above results would seem to relegate the local RAS to a subsidiary role in fertility. However, these results could be explained by the presence of a blood-testis barrier, which can be a significant block to the entry of drugs (see discussion in Vinson et al. 1997). Hence, at present the experimental evidence for a definitive role for the RAS in fertility is controversial. On the hand other, the effect of RAS blockade on a local RAS activity in other sites in the male reproductive tract has been investigated. In the epididymis, for example, electrophysiological studies using a short-circuit current technique demonstrated a stimulatory effect of AngII on the epididymal electrogenic ion transport. This effect was inhibitable by the addition of $\mathrm{AT}_{1}$ receptor antagonist, losartan, but not by $\mathrm{AT}_{2}$ receptor antagonist, PD123177, indicating a functional role of $\mathrm{AT}_{1}$ receptor in epididymal function (Leung et al. 1997b, 2002). In the prostate, blockade of $\mathrm{AT}_{1}$ and $\mathrm{AT}_{2}$ receptors inhibited AngII-stimulated sympathetic transmission. These data provide direct evidence in support of a functional role for the local RAS in modulating sympathetic transmission in the prostate, which may have important implications for the pathophysiology of BPH (Fabiani et al. 2001). Interestingly, the effects of AngII infusion and ACE inhibition on the RAS activity have been also examined in the testes. In that study, infusion of AngII decreased the local synthesis of testicular ACE mRNA (Schunkert et al. 1993), indicating that a local RAS activity is responsive to RAS inhibition. Nevertheless, the intrinsic RAS activity in male reproductive organs, and thus its implications for male reproduction, await further investigation.

\section{Conclusions}

The data reviewed above and summarized in Table 1 and Fig. 1 provide substantial evidence for local AngII production in various parts of the male reproductive system. While details of the pathways of AngII production need attention, the major issues of identification and localization are largely known. The detection of $\mathrm{AT}_{4}$ receptors in the prostate has brought into focus the need to consider the involvement of other angiotensin peptides besides AngII. The functions and regulation of local RAS are being elucidated: in particular (i) the importance of sperm-specific $\mathrm{ACE}, \mathrm{AT}_{1}$ receptor and angiotensinogen in sperm function and fertility, (ii) the involvement of a local RAS in the epididymis, a core segment for the maturation of sperm, and (iii) the likely involvement of the RAS in BPH. Future investigations in these areas are the most likely to lead to a fuller understanding of, and practical applications in, male fertility and disease.

\section{Acknowledgements}

The work was supported by the Research Grants Councils of Hong Kong (Project No: CUHK 4229/97 M, CUHK 4075/00 M and CUHK 4116/01 M), by the Chinese University of Hong Kong, and by the National Health and Medical Research Council of Australia.

\section{References}

Albiston AL, McDowall SG, Matsacos D, Sim P, Clune E, Mustafa T, Lee J, Mendelsohn FAO, Simpson RJ, Connolly LM et al. 2001 Evidence that the angiotensin IV (AT4) receptor is the enzyme insulin-regulated aminopeptidase. Fournal of Biological Chemistry 276 48623-48626.

Berg TJ, Solner CY, Lai J \& Soffer RL 1986 Immunohistochemical localization of two angiotensin I-converting isoenzymes in the reproductive tract of the male rabbit. Fournal of Histochemistry and Cytochemistry 34 753-760.

Campbell DJ 1987 Circulating and tissue angiotensin systems. Fournal of Clinical Investigation 79 1-6.

Campbell DJ \& Habener JF 1986 Angiotensinogen is expressed and differentially regulated in multiple tissues of the rat. Fournal of Clinical Investigation 78 31-39.

Cheuk BLY, Leung PS, Lo ACT \& Wong PYD 2000 Androgen control of cyclooxygenase expression in the rat epididymis. Biology of Reproduction 63 775-780.

Crandall DL, Herzlinger HE, Saunders BD, Zolotor RC, Feliciano L \& Cervoni P 1993 Identification and characterization of angiotensin II receptors in rat epididymal adipocyte membranes. Metabolism 42 511-515.

Crandall DL, Herzlinger HE, Saunders BD, Armellino DC \& Dral JG 1994 Distribution of angiotensin II receptors in rat and human adipocytes. Fournal of Lipid Research 35 1378-1385.

De Gasparo M, Catt KJ, Inagami T, Wright JW \& Unger TH 2000 Angiotensin II receptors. Pharmacological Reviewes 52 415-472.

Deschepper CF, Mellon SH, Cumin F, Baxter JD \& Ganong WF 1986 Analysis by immunocytochemistry and in situ hybridization of renin and its mRNA in kidney, testis, adrenal, and pituitary of the rat. PNAS $\mathbf{8 3} 7552-7556$.

Dinh DT, Frauman AG, Sourial M, Casley DJ, Johnston CI \& Fabiani ME 2001 $a$ Identification, distribution and expression of angiotensin II receptors in the normal human prostate and benign prostate hyperplasia. Endocrinology 142 1349-1356.

Dinh DT, Frauman AG, Casley DJ, Johnston CI \& Fabiani ME $2001 b$ Angiotensin AT(4) receptors in the normal human prostate and benign prostatic hyperplasia. Molecular and Cellular Endocrinology 184 187-192. 
Dinh DT, Frauman AG, Somers GR, Ohishi M, Zhuo J, Casley DJ, Johnston CI \& Fabiani ME 2002 Evidence for activation of the renin-angiotensin system in the human prostate: increased angiotensin II and reduced ATl receptor expression in benign prostatic hyperplasia. Fournal of Pathology 196 213-219.

Doan TN, Gletsu N, Cole J \& Bernstein KE 2001 Genetic manipulation of the renin-angiotensin system. Current Opinion in Nephrology and Hypertension 10 483-491.

Dostal LA, Kim SN, Schardein JL \& Anderson JA 1991 Fertility and perinatal/postnatal studies in rats with the angiotensin-converting enzyme inhibitor, quinapril. Fundamental and Applied Toxicology 17 $684-695$.

Dzau VJ, Ellison KE, Brody T, Ingelfinger J \& Pratt RE 1987 A comparative study of the distributions of renin and angiotensinogen messenger ribonucleic acids in rat and mouse tissues. Endocrinology $1202334-2338$.

El-Dorry HA, MacGregor JS \& Soffer RI 1983 Dipeptidyl carboxypeptidase from seminal fluid resembles the pulmonary rather than the testicular isoenzyme. Biochemical and Biophysical Research Communications 115 1096-1100.

Esther CR, Marino EM \& Bernstein KE 1997 The role of angiotensin-converting enzyme in blood pressure control, renal function, and male fertility. Trends in Endocrinology and Metabolism 8 181-186.

Fabiani ME, Sourial M, Thomas WG, Johnson CI \& Frauman AG 2001 Angiotensin II enhances noradrenaline release from sympathetic nerves of the rat prostate via a novel angiotensin receptor: implications for the pathophysiology of benign prostatic hyperplasia. Fournal of Endocrinology 171 97-108.

Grove KL \& Speth RC 1989 Rat epididymis contains functional angiotensin II receptors. Endocrinology 125 223-230.

Gur Y, Breitbart H, Rubinstein S \& Zamir N 1998 Angiotensin II induces acrosomal exocytosis in bovine spermatozoa. American Fournal of Physiology 275 E87-E93.

Hagaman JR, Moyer JS, Bachman ES, Sibony M, Magyar PL, Welch JE, Smithies O, Krege JH \& O'Brien DA 1998 Angiotensin-converting enzyme and male fertility. PNAS 95 $2552-2557$

Hohlbrugger G, Schweisfurth H \& Dahlheim H 1982 Angiotensin I converting enzyme in rat testis, epididymis and vas deferens under different conditions. Foumal of Reproduction and Fertility $\mathbf{6 5}$ 97-103.

Kessler SP, Rowe TM, Gomos JB, Kessler PM \& Sen GC 2000 Physiological non-equivalence of the two isoforms of angiotensin-converting enzyme. Fournal of Biological Chemistry 275 26259-26264.

Khanum A \& Dufau ML 1988 Angiotensin II receptors and inhibitory actions in Leydig cells. Fournal of Biological Chemistry 263 5070-5074.

Kim H, Krege JH, Gluckman KD, Hagaman JR, Hodgin JB, Best CF, Jenette JC, Coffman TM, Maeda N \& Smithies O 1995 Genetic control of blood pressure and the angiotensinogen locus. PNAS 92 2735-2739.

Kitami Y, Okura T, Marumoto K, Wakamiya R \& Hiwada K 1992 Differential gene expression and regulation of type-1 angiotensin II receptor subtypes in the rat. Biochemical and Biophysical Research Communications 188 446-452.

Kohn FM, Dammshauser I, Neukamm C, Renneberg H, Siems WE, Schill WB \& Aumuller Gi $1998 a$ Ultrastructural localization of angiotensin-converting enzyme in ejaculated human spermatozoa. Human Reproduction 13604610.

Kohn FM, Muller C, Drescher D, Neukamm C, Henkel Ri, Hagele W, Hinsch E, Habenicht UF \& Schill WB $1998 b$ Effect of angiotensin converting enzyme (ACE) and angiotensins on human sperm functions. Andrologia $30207-215$.

Krege JH, John SW, Langenbach LL, Hodgin JB, Hagaman JR, Bachman ES, Jennette JC, O'Brien DA \& Smithies O 1995
Male-female differences in fertility and blood pressure in ACE-deficient mice. Nature 375 146-148.

Lam SY \& Leung PS 2002 A locally generated angiotensin system in rat carotid body. Regulatory Peptides 107 97-103.

Leung PS \& Carlsson PO 2001 Tissue renin-angiotensin system: its expression, localization, regulation and potential role in the pancreas. Fournal of Molecular Endocrinology 26 155-164.

Leung PS, Chan HC, Fu LXM, Chew SBC \& Wong PYD $1997 a$ Angiotensin II receptors: localization of type I and type II in rat epididymides of different developmental stages. Fournal of Membrane Biology 157 97-103.

Leung PS, Chan HC, Fu LXM, Zhou WL \& Wong PYD $1997 b$ Angiotensin II receptors, $\mathrm{AT}_{1}$ and $\mathrm{AT}_{2}$ in the rat epididymis: immunocytochemical and electrophysiological studies. Biochimica et Biophysica Acta 1357 65-72.

Leung PS, Yao XQ, Chan HC, Fu LXM \& Wong PYD $1998 a$ Differential gene expression of angiotensin II receptor subtypes in the epididymides of mature and immature rats. Life Sciences $\mathbf{6 2}$ 461-468.

Leung PS, Chan HC, Chung YW, Wong TP \& Wong PYD $1998 b$ The role of local angiotensins and prostaglandins in the control of anion secretion by rat epididymis. Fournal of Reproduction and Fertility Supplement 53 15-22.

Leung PS, Wong TP \& Sernia C 1999 Angiotensinogen expression by rat epididymis: evidence for an intrinsic, angiotensin-generating system. Molecular and Cellular Endocrinology 155 115-122.

Leung PS, Wong TP, Lam SY, Chan HC \& Wong PYD 2000 Testicular hormonal regulation of the renin-angiotensin system in the rat epididymis. Life Sciences 66 1317-1324.

Leung PS, Fung ML \& Sernia C 2001 Chronic hypoxia induced down-regulation of angiotensinogen expression in rat epididymis. Regulatory Peptides 96 143-149.

Leung PS, Wong TP, Chung YW \& Chan HC 2002 Androgen dependent expression of $\mathrm{AT}_{1}$ receptor and its regulation of anion secretion in rat epididymis. Cell Biology International 25 117-122.

Magnan J \& Regoli D 1979 Characterization of receptors for angiotensin in the rat vas deferens. Canadian Fournal of Physiological Pharmacology 57 417-423.

Maruta H \& Arakawa K 1983 Confirmation of direct angiotensin formation by kallikrein. Biochemical Fournal 213 193-200.

Millan MA \& Aguilera G 1988 Angiotensin II receptors in testes. Endocrinology 122 1984-1990.

Mukhopadyay AK, Cobilanschi J, Brunswig-Spikenheier B \& Leidenberger FA 1995 Relevance of the tissue prorenin-renin-angiotensin system to male reproductive physiology. In Tissue Renin-Angiotensin Systems, pp 269-277. Eds AK Mukhopadyay \& MK Raizada. New York: Plenum.

Nassis L, Frauman AG, Ohishi M, Zhuo J, Casley DJ, Johnston CI \& Fabiani ME 2001 Localisation of angiotensin-converting enzyme in the human prostate: pathological expression in benign prostatic hyperplasia. Fournal of Pathology 195 571-579.

Okuyama A, Nonomura N, Nakamura M \& Namiki M 1988 Renin-angiotensin system. Archives of Andrology 21 169-180.

O'Mahony OA, Djahanbahkch O, Mahmood T \& Vinson GP 2000 Angiotensin II in human seminal fluid. Human Reproduction $\mathbf{1 5}$ 1345-1349.

Pandey KN, Maki M \& Inagami T 1984a Detection of renin mRNA in mouse testis by hybridization with renin cDNA probe. Biochemical and Biophysical Research Communications 125 662-667.

Pandey KN, Misono KS \& Inagami T $1984 b$ Evidence for intracellular formation of angiotensins: coexistence of renin and angiotensin-converting enzyme in Leydig cells of rat testis. Biochemical and Biophysical Research Communications 122 1337-1343.

Parmentier M, Inagami T, Poschet R \& Desclin JC 1983 Pituitary dependent renin-like immunoreactivity in rat testis. Endocrinology 112 1318-1323. 
Phillips MI, Speakman EA \& Kimura B 1993 Levels of angiotensin and molecular biology of the tissue renin angiotensin systems. Regulatory Peptides 43 1-20.

Pinterova L, Krizanova O \& Zorad S 2000 Rat epididymal fat tissue express all components of the renin-angiotensin system. General Physiology and Biophysics 19 329-334.

Poisner AM 1998 The human placental renin-angiotensin system. Frontiers in Neuroendocrinology 19 232-252.

Ramaraj P, Kessler SP, Comenares C \& Sen GC 1998 Selective restoration of male fertility in mice lacking angiotensin-converting enzymes by sperm-specific expression of the testicular isoenzyme. Fournal of Clinical Investigation 102 371-378.

Reid IA, Morris BJ \& Ganong WF 1978 The renin-angiotensin system. Annual Review of Physiology 40 377-410.

Schunkert H, Ingelfinger JR, Hirsch AT, Pinto Y, Remme WJ, Jacob H \& Dzau AJ 1993 Feedback regulation of angiotensin enzyme activity and mRNA levels by angiotensin II. Circulatory Research 72 312-318.

Sibony M, Gasc F, Soubrier F, Alhenc-Gelas JM \& Corvol P 1993 Gene expression and tissue localization of the two isoforms of angiotensin I converting enzyme. Hypertension 21 827-835.

Spence SG, Cukierski MA, Manson JM, Robertson RT \& Eydelloth RS 1995 Evaluation of the reproductive and developmental toxicity of the $\mathrm{AT}_{1}$-selective angiotensin II receptor antagonist losartan in rats. Teratology 51 383-397.

Speth RC, Daubert DL \& Grove KL 1999 Angiotensin II: a reproductive hormone too? Regulatory Peptides 79 25-40.

Stroth U \& Unger T 1999 The renin-angiotensin system and its receptors. Fournal of Cardiovascular Pharmacology 33 (Suppl 1) 21-28.

Sum CS \& Cheung WT 1995 Characterization of contractile response to angiotensin in epididymal rat vas deferens. Pharmacology 51 105-111.

Tempfer CB, Moreno RM \& Gregg AR 2000 Genetic control of fertility and embryonic waste in the mouse: a role for angiotensinogen. Biology of Reproduction 62 457-462.
Tsuchida S, Matsusaka T, Chen X, Okubo S, Niimura F, Nishimura H, Fogo A, Utsunomiya H, Inagami T \& Ichikawa I 1998 Murine double nullizygotes of the angiotensin type $1 \mathrm{~A}$ and $1 \mathrm{~B}$ receptor genes duplicate severe abnormal phenotypes of angiotensinogen nullizygotes. Fournal of Clinical Investigation 101 $755-760$.

Uchendu CN 1995 Renin-like activity in the rat epididymis. Indian Fournal of Physiological Pharmacology 39 204-208.

Vinson GP, Puddefoot JR, Ho MM, Barker S, Mehta J, Saridogan E \& Djahanbakhch O 1995 Type 1 angiotensin II (AT1) receptors in rat and human sperm. Fournal of Endocrinology 144 369-378.

Vinson GP, Mehta J, Evan S, Matthews S, Puddefoot JR, Saridogan E, Holt VW \& Djahanbakhch O 1996 Angiotensin II stimulates sperm motility. Regulatory Peptides 67 131-135.

Vinson GP, Saridogan E, Puddefoot JR \& Djahanbakhch O 1997 Tissue renin-angiotensin systems and reproduction. Human Reproduction 12 651-662.

Williams TA, Villard E, Prigent Y, Daoboune JP \& Soubrier F 1995 A genetic study of angiotensin-converting enzyme in human semen. Molecular and Cellular Endocrinology 107 215-219.

Wong PYD \& Uchendu CN 1991 Studies on the renin-angiotensin system in primary monolayer cell cultures of the rat epididymis. fournal of Endocrinology 131 289-293.

Wong PYD, Chan HC, Leung PS, Chung YW, Lee WM, Ng V \& Dun NJ 1999 Regulation of anion secretion by cyclo-oxygenase and prostanoids in cultured epididymal epithelia from the rat. Fournal of Physiology $\mathbf{5 1 4}$ 809-820.

Zhao W, Leung PY, Cheng-Chew SB, Chan HC \& Wong PYD 1996 Localization and distribution of angiotensin II in the rat epididymis. Fournal of Endocrinology 149 217-222.

Received in final form 9 November 2002 Accepted 24 November 2002 